УДК 636.09:616-092.4:579.86, DOI 10.31210/visnyk2018.02.23

(C) 2018

Пінчук Н. Г., кандидат ветеринарних наук

Державний науково-контрольний інститут біотехнології і штамів мікроорганізмів (ДНКІБШМ)

\title{
ПАТОГЕННІСТЬ ТА ВІРУЛЕНТНІСТЬ ІЗОЛЯТІВ ERYSIPELOTHRIX RHUSIOPATHIAE
}

\section{Рецензент - доктор ветеринарних наук В. В. Чумаченко}

Erysipelothrix rhusiopathiae неоднорідний за здатністю до утворення токсинів, ферментів та інших факторів патогенності. У даній статті нами було охарактеризовано 54 польові ізоляти Erysipelothrix rhusioраthiаe, виділені з різних регіонів України, від різних видів тварин і встановлено, щз $52 \%$ ізолятів належсть до середньо вірулентних; найменший відсоток (13\%) становлять високо вірулентні і $35 \%$ - слабо вірулентні ізоляти. Необхідно зазначити, щуо високо вірулентні ізоляти були виділені від загиблих свиней Південного-Східного регіону Украӥни (Автономна республіка Крим із м. Севастополь, Дніпропетровська, Запорізька, Кіровоградська, Миколаївська, Одеська та Херсонська області). Отримані результати досліджень стали підставою для відбору 7 високо вірулентних ізолятів Erysipelothrix rhusiopathiae, які можуть бути використані як контрольні при контролюванні якості вакцин жсвих та інактивованих проти бешихи свиней на лабораторних білих мишах.

Ключові слова: бешиха свиней, вірулентність, ізоляти, Erysipelothrix rhusiopathiae, патогенність.

Постановка проблеми. Одним із головних напрямів ветеринарної науки і практики є створення та виробництво засобів діагностики і профілактики хвороб тварин, захист країни від заносу збудників особливо небезпечних захворювань тварин. У зв'язку з цим, забезпечення практики ветеринарної медицини ефективними лікувально-профілактичними препаратами є одним 3 головних завдань.

Сучасні дослідження з удосконалення специфічної профілактики бешихи повинні бути акцептовані не лише на покращення антигенної «якості» вакцин, але й на підвищення біодоступності, адекватності вакцинного антигенного матеріалу імунній системі тварини та іiі функціональному потенціалу.

Бешиха свиней (Erysipelas suum) - одне з найбільш поширених і небезпечних захворювань, переважно свиней у віці від 3-х до 12-ти місяців, яке характеризується за гострого і підгострого перебігів септицемією, запальною еритемою шкіряного покриву, гастроентеритом і гіперплазією селезінки, а за хронічного - дерматитом, бородавчастим або виразковим ендокардитом i серозно-фібринозними артритами.

Захворюваність свиней на бешиху коливається в межах 20-30\%, летальність - 55-80\%.

Окрім свиней хворіють велика та дрібна рогата худоба, коні, північні олені, багато диких ссавців, домашні та дикі птахи. Серед домашніх та диких тварин, птахів і особливо гризунів широко розповсюджено мікробоносійство. Збудника бешихи часто виявляють в організмі морських та річкових риб, дельфінів, комах і членистоногих. Хворіє бешихою і людина $[1,6]$.

Одним із найбільш небезпечних джерел є свині з гострим перебігом бешихи, за якого в клінічний період, а також деякий час після видужання із сечею та калом виділяється велика кількість вірулентних бактерій. Чим більше в господарстві у весняний час відмічається гострих випадків бешихи, тим частіше спостерігаються повторні спалахи цього захворювання, і тим більша небезпека перетворення таких господарств у стаціонарні вогнища інфекції.

Дуже небезпечними $є$ й хронічні форми бешихи, коли бактерії знаходяться не лише в уражених тканинах, але і виділяються у зовнішнє середовище $з$ сечею та калом.

Джерелом інфекції можуть бути і клінічно здорові свині. На основі цього, носійство бактерій Er. rhusiopathiae здоровими свинями необхідно розглядати як латентну інфекцію, за якої організм своїми захисними біологічними реакціями обмежує можливість проникнення бактерій в кровоносне русло і внутрішні органи. Проте такий стан не стійкий: він може перейти у безсимптомне перехворювання, після чого тварина набуває імунітет або (за несприятливих умов, які послаблюють резистентність організму) бактерії можуть активізуватися, вийти за межі первинного джерела і викликати захворювання 3 клінічними ознаками $[2,4-5]$.

Поросята-сисуни стійкі до бешихи. Гостра септична форма захворювання відмічається у них дуже рідко, в основному у віці більше 40 днів і частіше в господарствах, де практикують раннє відлучення сисунів від матерів. 


\section{ВЕТЕРИНАРНА МЕДИЦИНА}

Найбільш сприйнятливі до бешихи ремонтний та молодняк на відгодівлі. Дорослі свині більш стійкі до захворювання.

Бешиха свиней відноситься до групи інфекційних захворювань із вираженою сезонною періодичністю. Захворюваність бешихою помітно підвищується 3 настанням весни. Кількість тварин, хворих бешихою, підвищується, а влітку та на початку осені досягає максимуму. Зимою захворюваність значно знижується. В Криму та на півдні України в умовах теплої зими захворювання може реєструватися і взимку, що необхідно враховувати при складанні графіка вакцинації.

Епізоотологічною особливістю бешихи є характер перебігу іiі в неблагополучних господарствах: захворювання ніколи не охоплює все поголів'я неблагополучного господарства. Найчастіше бешиха проявляється або у вигляді поодиноких випадків, або у формі коротких спалахів, які повторяються через невизначені проміжки часу.

Аналіз останніх наукових досліджень і публікацій 3 даної проблеми. Erysipelothrix rhusiopathiae відносять до убіквітарних мікроорганізмів, які в залежності від умов знаходження, можуть мати неоднакові морфологічні, вірулентні, антигенні та імуногенні властивості.

Erysipelothrix rhusiopathiae неоднорідний за здатністю до утворення токсинів, ферментів та інших факторів патогенності [6].

Не дивлячись на те, що збудник бешихи свиней належить до числа мікроорганізмів, які легко виділяти та ідентифікувати, без використання складних діагностичних засобів та методик, питання про патогенність Erysipelothrix rhusiopathiae та наявність факторів патогенності, які приймають участь у механізмах виникнення і розвитку патологічних процесів, залишається важливим та актуальним питанням.

Мета досліджень - вивчити патогенність та вірулентність ізолятів Erysipelothrix rhusiopathiae, виділених у різних регіонах України від різних видів тварин.

Матеріали і методи досліджень. Матеріалом для дослідження були 47 ізолятів Erysipelothrix rhusiopathiae, виділені від свиней із септичною формою захворювання, за хронічного та атипового перебігів хвороби, а також від клінічно здорових свиней; 2 ізоляти, виділені від птиці (курей-несучок); 3 - від індиків; 2 - від голубів.

У цілому, у період з 2012 по 2017 рр. було виділено та ідентифіковано 54 ізоляти Erysipelothrix rhusiopathiae 3 різних регіонів України, від різних видів тварин.

Культурально-морфологічні властивості Erysipelothrix rhusiopathiae вивчали шляхом культи- вування бактерій у рідких та твердих поживних середовищах: м'ясопептонному бульйоні (МПБ) та агарі (МПА), м'ясопептонному бульйоні та агарі Хоттінгера (МПБХ, МПАХ), триптонсоєвому бульйоні (ТСБ) та агарі (ТСА), а також на кров'яному агарі; фарбуванням мазків, виготовлених з добових культур, за Грамом.

Біохімічні властивості культур визначали шляхом культивування в поживному середовищі «Основа бульйону з феноловим червоним М 054, виробництва «Himedia» 3 арабінозою, глюкозою, дульцитом, мальтозою, лактозою, манітом, маннозою, рамнозою, саліцином, сорбітолом, сахарозою, ксилозою, галактозою, фруктозою, адонітом, інуліном, інозитом, целобіозою, мелібіозою, трегалозою.

Патогенні властивості культур Er. Rhusiopathiae вивчали на лабораторних білих мишах (по 5 голів на розведення) шляхом введення добової бульйонної культури Erysipelothrix rhusiopathiae у розведеннях від 10-1 до 10-7 в об'ємі $0,2 \mathrm{~cm}^{3}$ підшкірно. Термін спостереження - 10 діб.

Вірулентні властивості культур Erysipelothrix rhusiopathiae вивчали шляхом визначення LD50. Для визначення LD50 готували послідовні десятикратні розведення сухої культури, починаючи від 10-3 до 10-7 на фізіологічному розчині $\mathrm{pH}$ $7,2-7,4$ (на кожне розведення брали іншу піпетку) і вводили підшкірно білим мишам масою 1820 г по $0,1 \mathrm{~cm}^{3}$ із розведень від 10-3 до $10-7$ (із розрахунку по 6 лабораторних тварин на кожне розведення). Вірулентність культур Erysipelothrix rhusiopathiae оцінювали по $50 \%$ летальній дозі для лабораторних білих мишей. Визначення LD50 проводили за методом Кербера в модифікації Ашмарина.

Результати досліджень. При виконанні поставлених завдань нами були вивчені та охарактеризовані польові ізоляти Erysipelothrix rhusiopathiae, виділені з різних регіонів України, від різних видів тварин і встановлено, що за культурально-морфологічними та біохімічними властивостями культури були типовими, 3 характерними для даного виду властивостями.

Ступінь вірулентності $€$ однією з ознак, яка дозволяс диференціювати штами та ізоляти збудника бешихи свиней та умовно розділяти їх на 4 групи:

- високо вірулентні - LD50 становить до 100 КУО/тварину (білу мишу);

- середньо вірулентні - LD50 становить до 10000 КУО/тварину (білу мишу);

- слабо вірулентні - LD50 становить більше 10000 КУО/тварину (білу мишу);

- авірулентні. 


\section{ВЕТЕРИНАРНА МЕДИЦИНА}

У результаті проведених досліджень встановлено, що до групи високо вірулентних культур Erysipelothrix rhusiopathiae належали 7 ізолятів (6- виділених $з$ патологічного матеріалу загиблих свиней та 1 - від індиків; Log LD50 становив 1.7-2.2). Дещо нижча вірулентність виявлена у 24 культур Erysipelothrix rhusiopathiae, виділених 3 патологічного матеріалу загиблих свиней та 2 - від індиків, 1 - від курей-несучок, 1 - від голуба; Log LD50 становив 2.93-4.05.

17 ізолятів Erysipelothrix rhusiopathiae, виділених від свиней, 1 - від курей-несучок та 1 - від голуба було віднесено до слабо вірулентних ( $\log$ LD50 становив $>6.0$ ).

Результати вивчення вірулентності ізолятів Erysipelothrix rhusiopathiae представлено на рисунку 1.

3 результатів досліджень, представлених на рис. 1, видно, що $52 \%$ ізолятів належить до середньо вірулентних; найменший відсоток (13\%) становлять високо вірулентні і $35 \%$ - слабо вірулентні ізоляти Erysipelothrix rhusiopathiae.

Крім того, необхідно зазначити, що високо вірулентні ізоляти були виділені від загиблих свиней Південного-Східного регіону України (Автономна республіка Крим 3 м. Севастополь, Дніпропетровська, Запорізька, Кіровоградська, Миколаївська, Одеська та Херсонська області).

Отримані результати досліджень стали підставою для відбору 7 високо вірулентних ізолятів Erysipelothrix rhusiopathiae, які можуть бути використані як контрольні при контролюванні якості вакцин живих та інактивованих проти бешихи свиней на лабораторних білих мишах.

Висновки. У період з 2012 по 2017 рр. було виділено та ідентифіковано 54 ізоляти Erysipelothrix rhusiopathiae 3 різних регіонів
України від різних видів тварин.

Вивчено культурально-морфологічні, біохімічні властивості 54 ізолятів Erysipelothrix rhusiopathiae, виділених від свиней із септичною формою захворювання, за хронічного та атипового перебігів хвороби, а також від клінічно здорових свиней; від птиці (курей-несучок), індиків та голубів і визначено їх $\mathrm{LD}_{50}$

Встановлено, що 52 \% польових ізолятів Erysipelothrix rhusiopathiae належить до середньо вірулентних; найменший відсоток (13\%) становлять високо вірулентні і $35 \%$ - слабо вірулентні ізоляти.

Нами було відібрано 7 високо вірулентних штамів Erysipelothrix rhusiopathiae і визначено їх $\mathrm{LD}_{50}$, які можуть бути використані як контрольні при контролюванні якості вакцин живих та інактивованих проти бешихи свиней на лабораторних білих мишах.

Вимоги «European Pharmacopoeia 0064» та «ДСТУ 6079:2009» щодо контролювання якості вакцин проти бешихи свиней за показниками «ефективність»/«імуногенність» передбачають проведення дослідження на цільових видах тварин 3 їх послідуючим, через рекомендований термін після вакцинації, контрольним зараженням патогенними для свиней сероваріантами $E r$. rhusiopathiae $[3,7]$.

Культури, що мали високу вірулентність для білих мишей можуть бути використані при проведенні подальших досліджень з відбору кандидатів у контрольні 3 епізоотичних ізолятів Er. rhusiopathiae, виділених із різних регіонів України, та створення стандартної заражаючої культури Er. rhusiopathiae серотипів 1 та 2 для контролю якості вакцин проти бешихи свиней (живих та іактивованих) на свинях.

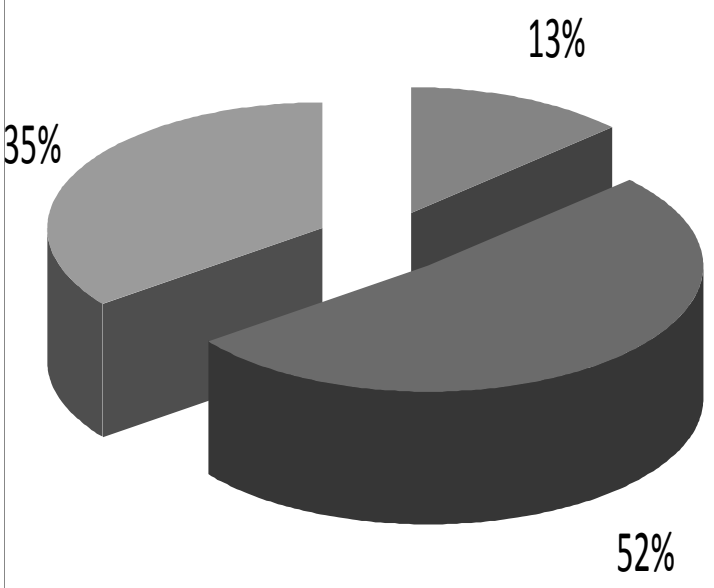

високо вірулентні ізоляти

середньо вірулентні

ізоляти

слабо вірулентні

ізоляти

Рис. 1. Результати вивчення вірулентності ізолятів Erysipelothrix rhusiopathiae 


\section{БІБЛІОГРАФІЯ}

1. Cussler K. 100 years of erysipelas prophylaxis: significance and reduction of animal experiments / Cussler K., Balks E. // ALTEX. - 2001. - Vol. 18 (1). - P. 29-33.

2. Eames G. J., Turner M. J., Catt R. E. Serotypes of Erysipelothrix rhusiopathiae in Australian pigs, small ruminants, poultry and captive wild birds and animals // Aust. Vet. J. - 1998. - Vol. 65. - P. 249-252.

3. European pharmacopoeia 6.0. Swine erysipelas vaccine (inactivated), 01/2014:0064.

4. Pasteur L., Thuillier L. Мйmoires et communications: La vaccination du rouget des pores a laide

\section{ANNOTATION}

Pinchuk N. G. Pathogenicity and virulence of Erysipelothrix Rhusiopathiae isolatives.

Erysipelothrix rhusiopathiae is heterogeneous in the ability to form toxins, enzymes and other pathogenicity factors. Despite the fact that the pathogens of pigs' erysipelas belong to the number of microorganisms that are easy to isolate and identify, without using complex diagnostic tools and techniques, the issue of the pathogenicity of Erysipelothrix rhusiopathiae and the presence of pathogenic factors involved in the mechanisms of the onset and development of pathological processes remains.

The material for the study was 47 isolates of Erysipelothrix rhusiopathiae, isolated from pigs with a septic form of the disease, in chronic and atypical course of the disease, and from clinically healthy pigs; 2 isolates are isolated from poultry (laying hens); 3 - from turkeys; 2 - pigeons.

In this article we have studied and characterized 54 field Erysipelothrix rhusiopathiae isolates isolated from different regions of Ukraine from different species of animals and found that $52 \%$ of isolates belong to medium virulent; the smallest percentage $(13 \%)$ is highly virulent and $35 \%$, respectively, weakly virulent isolates.

As a result of the studies, it was found that 7 iso- $\mathrm{du}$ virus mortel attйnuй de cetti maladie. // CRL'Acad Sei Paris 97:1163-1169. - 1883.

5. Protective effect of $\mathrm{NaOH}$-extracted Erysipelothrix rhusiopathiae vaccine in pigs / T. Kitajima, E. Oishi, K. Amimoto, S. Ui et al. // J Vet Med Sci. - 1998. - № 60 (1). - P. 9-14.

6. Wood R.L. Erysipelas / In Diseases of swine 8th ed. / B. E. Straw, S. D’Allaire, W.L. Mengeling et al. - Iowa StateUniversity Press, Ames, 1999. P. 419-430.

7. ДСТУ 6079:2009 Вакцина жива суха проти бешихи свиней. Технічні умови.

lates belonging to the group of highly virulent cultures Erysipelothrix rhusiopathiae ( 6 isolated from pathological material of dead pigs and 1 - from turkeys; $\log \mathrm{LD}_{50}$ was 1.7-2.2). A slightly lower virulence was found in 24 cultures of Erysipelothrix rhusiopathiae isolated from the pathological material of dead pigs and 2 from turkeys, 1 from chickens, 1 - from the pigeon; $\log \mathrm{LD}_{50}$ was 2.93-4.05. 17 isolates of Erysipelothrix rhusiopathiae isolated from pigs, 1 from laying hens and 1 from the pigeon were classified as weakly virulent $\left(\log \operatorname{LD}_{50}>6.0\right)$. It should be noted that highly virulent isolates were isolated from the dead pigs of the South-East region of Ukraine (Autonomous Republic of Crimea from Sevastopol, Dnipropetrovsk, Zaporizhzhia, Kirovograd, Mykolayiv, Odesa and Kherson regions).

The obtained results of the research became the basis for selection of 7 highly virulent isolates of Erysipelothrix rhusiopathiae, which can be used as controls for controlling the quality of vaccines live and inactivated against white skinned pigs in laboratory white mice.

Key words: pigs erysipelas, virulence, isolates, Erysipelothrix rhusiopathiae, pathogenicity. 